\title{
静脈造影における造影㘊の混和性と撮影体位について
}

鳥取大学医学部付属病院中央放射線部

（部長・阿 武 保 郎）

角原重·利・国岡孝志

（論文受付昭和 43 年 8 月 15 日）

\section{DISTRIBUTION OF CONTRAST AGENTS IN VEIN AND POSITIONS OF THE PATIENTS IN VENOGRAPHY}

\section{By Shigetoshi KadoHara}

TAKASHI KUNIOKA

Central Dep. of Radiology, Tottori Univ. School of Medicine, Yonago, Japan.

(Article recieved Aug. 1968)

\section{Summary}

Experimental and clinical studies on the distribution of the contrast agents in vein indicate that the gravity plays a main role.

As the hyperbaric contrast agents preferentially flow beneath the blood, posterior walls of the veins are clearly delineated contray to the poor visualization of the anterior walls in supine position. To avoid this disadvantage, the authors stressed that additional to supine, prone or upright lateral and anteroposterior projection were advisable.

\section{は じめ に}

近年血管造影は連続撮影装置，同時=方台撮影装置の 開発，造影剤の改良等によりその頻度は増加の一途をた どっており，中でも Seldinger 法により動脈の撰択的造 影, 静脈造影などが比較的簡単に行なわれるようになっ たのでますます普及すると思われる。このような血管造 影において血液と造影剤とは泿和性の良いものほどX線 学上一般に好ましいとされている。しかし静脈造影のよ うな血流の遅い血管造影に执いては必ずしも血液と造影 剤は立分な混和性を示さないととがあり，診断上好まし

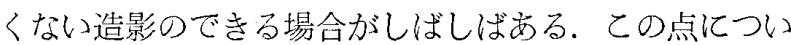
て本邦ではあまり研究されていないので，われわれは造 影剂と血液の混和性について実験を試み.との結果をむ とに臨未例についてあ検討したので報告する。

\section{I 基 礎 実 験}

\section{1. 実験材料}

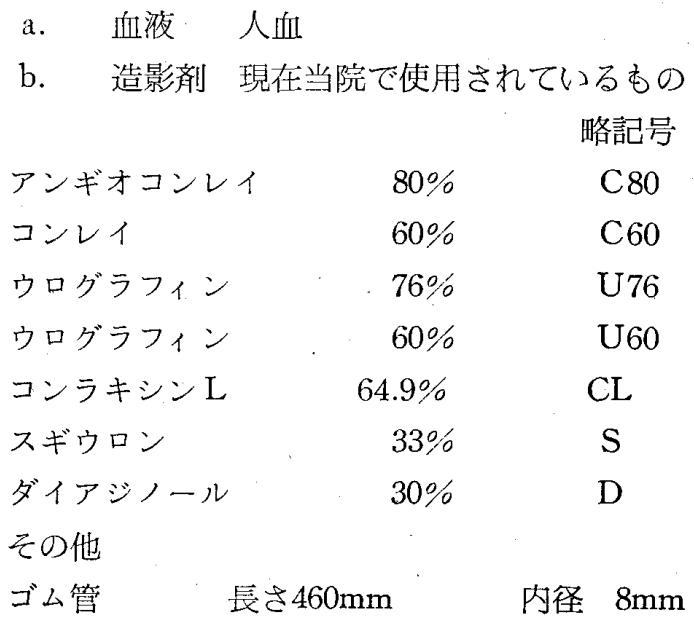




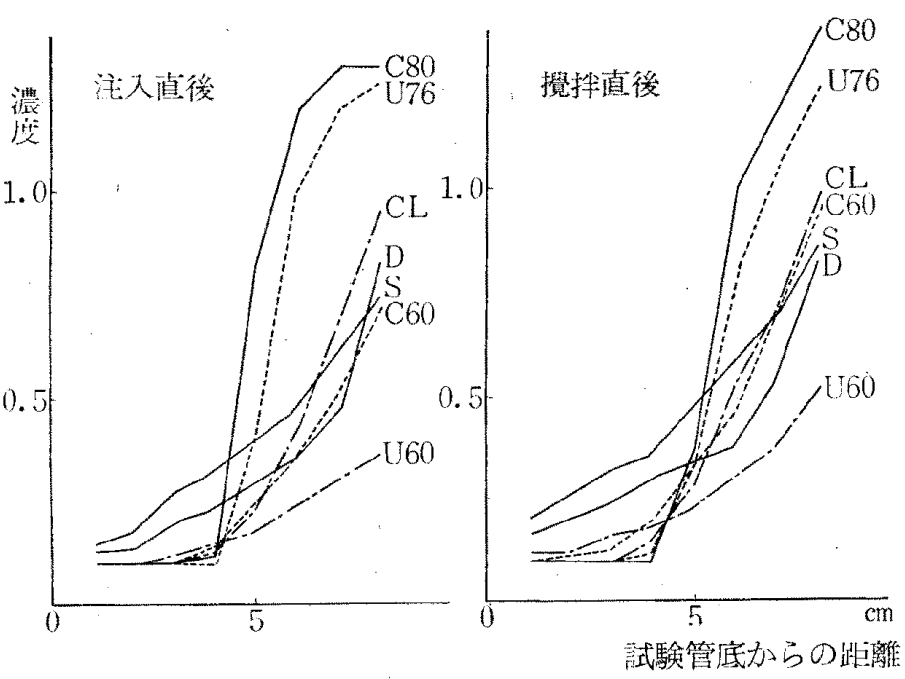

図 1

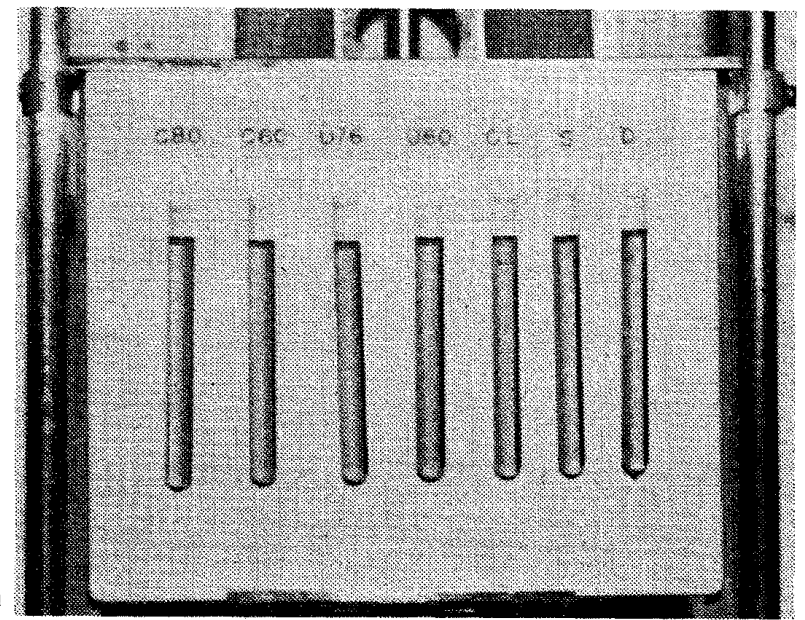

写真 1
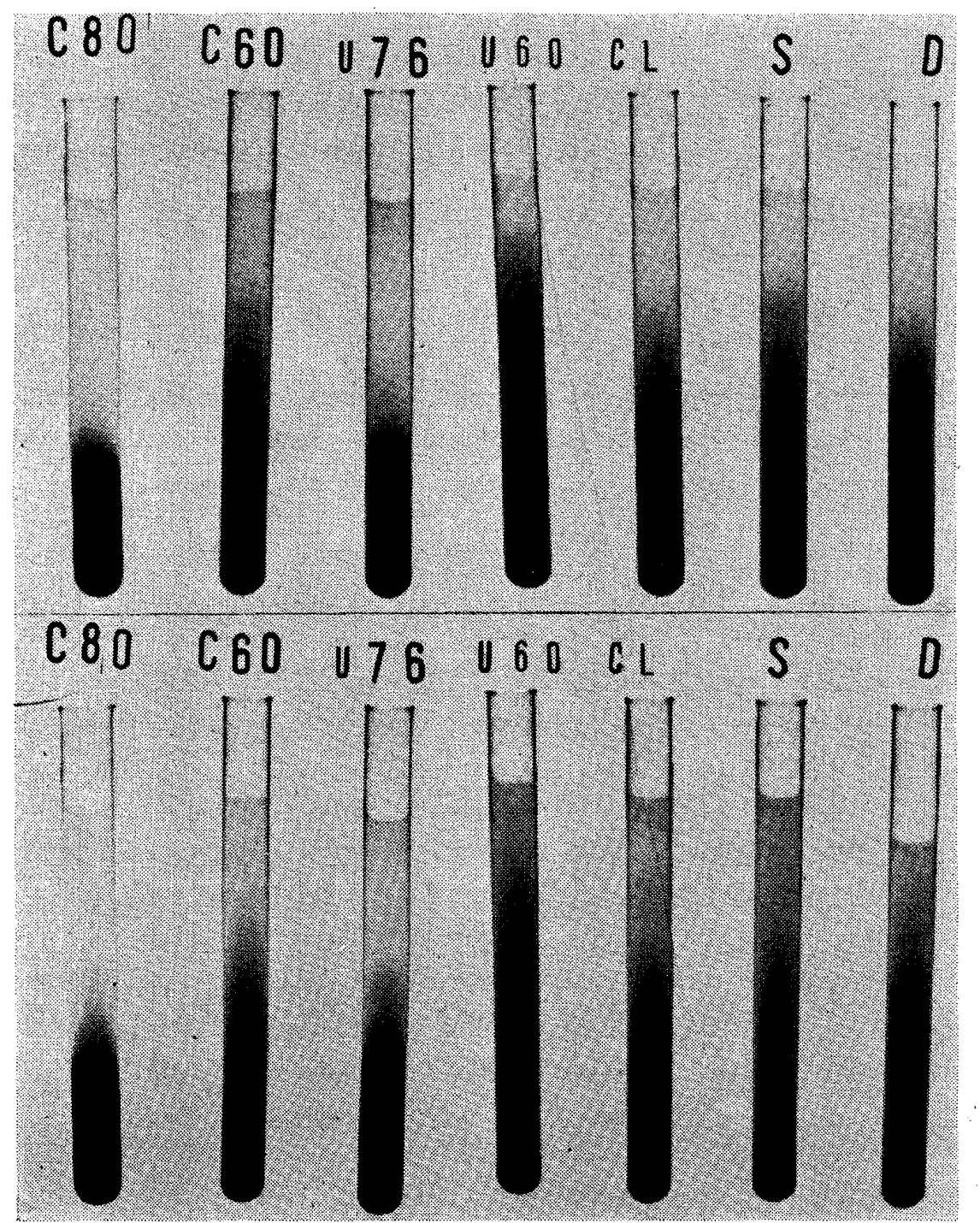

写真2上 直後, 下 筧找後
試験䈏 深さ $150 \mathrm{~mm}$ 口佳 $8 \mathrm{~mm}$

濃度評東点光電式

撮影装犆 東芝KXO-15型

X線管球 ロータノ一ト，篗点 $1.5 \times 1.5 \mathrm{~mm}$

増感紙 極光 FS

フィルム 富士 $\mathrm{KX}$

グリッドMSブレンデ(三田壆) $5: 1$

\section{2, 実験方法}

現在当院で使用されている各種造 影剂圭用意した試験管（写真1）に 初积液を备々 $10 \mathrm{cc}$ 注入し直後。造 影剂筞各々 $5 \mathrm{cc}$ 管壁を位わ甘て静 加汇注人して，そのままで撮影した

(写真2上)，次にフィルムを取替

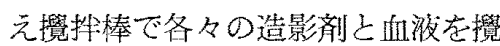
抖して撮影した。(写真2下)また各 試験管の踣度は濃度計で測定した (図 1)

次に血管を仮定したゴん管を使用 して試験管の場合と同様すぐ撮影で きるように用意したゴム管(写真 3) に血液をみたし，他端から掹液が流 出するようにして注大端より造影剤 を注入しながら側加ら撮影した (写真 4 ) 更に血腹の流動性を考虑し て写真 3 と同様に血液をみたしたゴ ム管に血液を一方より流出するよう 
にし，他端から造影剂と血液を別々に注射器で注入しな がら撮影した（写真 5 )。立位状態を仮定してゴム管を 立てて写真 3 と同様に撮影した。（写真 6)

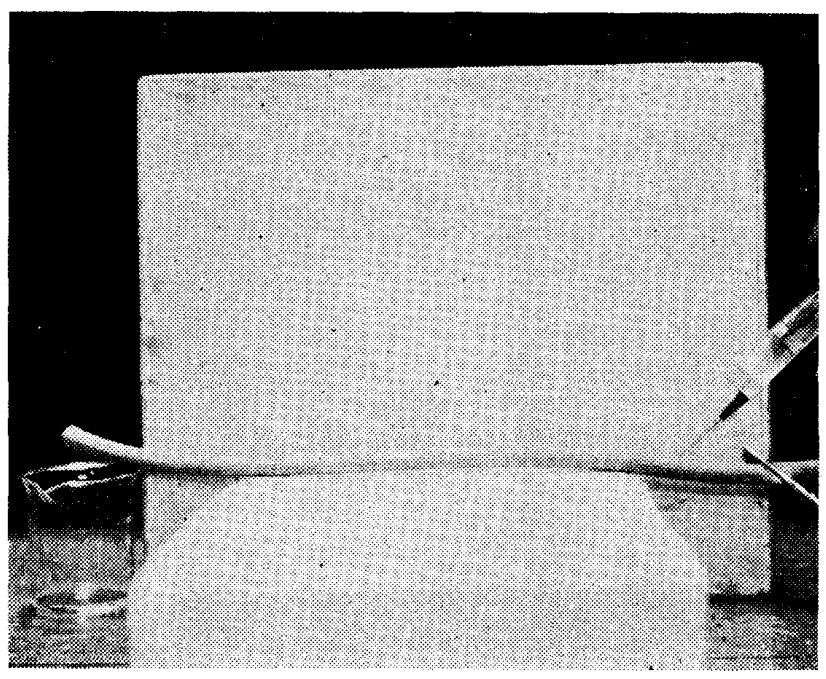

写真 3

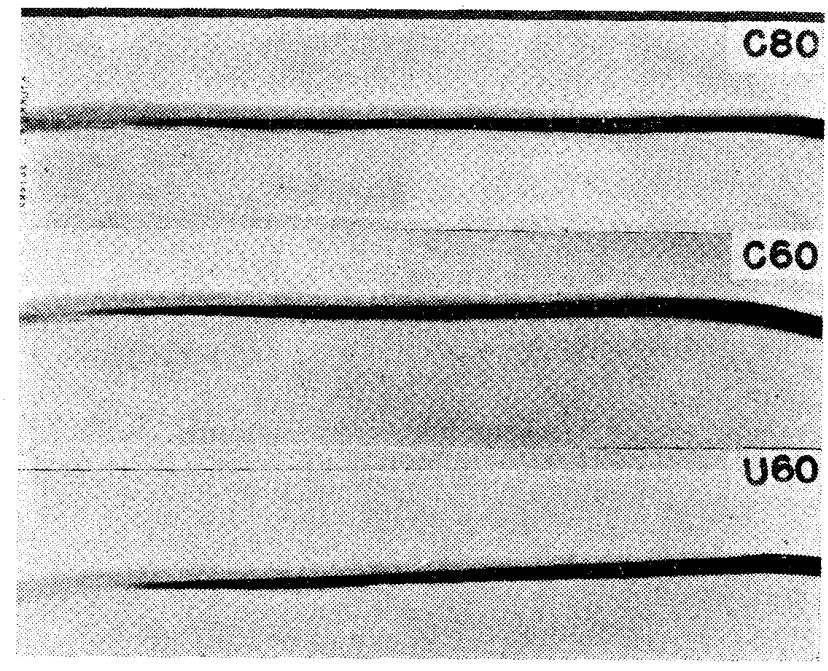

写真 4：側方向上壁部が造影されていない

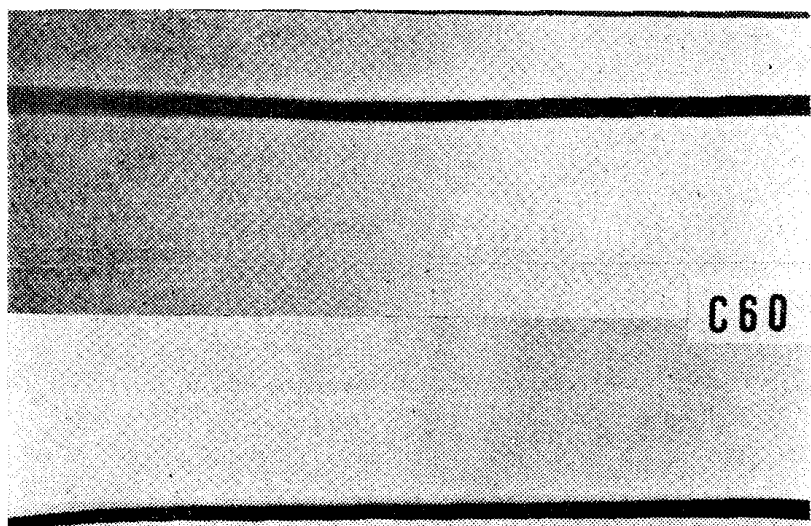

写真5：上：正面：全周造影されているが胃受ける 下：側面：上壁部の造影をみなり
写真6：立位全周造影

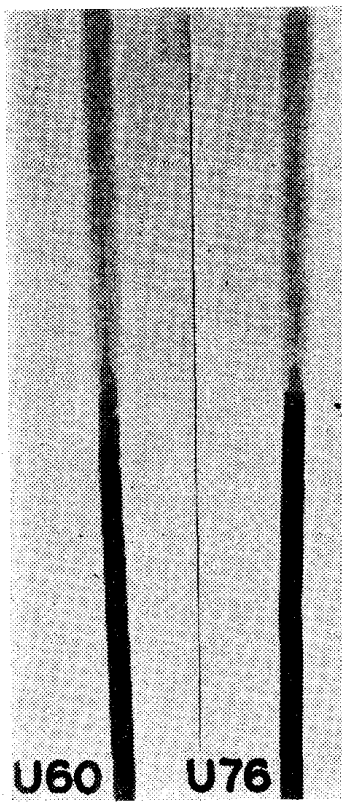

\section{3. 結 果}

試験管での写真 2 および咸 1

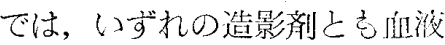
と充分な混和を示さずヨード含 有率の低いものが高いものに比 較してわずかによく混和してい る程度で覺排後も攪拌前と活々 んど変化のないことがわかる。 まな、ゴム管を使用した等基4 では造影㓣はゴム管の下部に層 龙形成し，注入された造影剤の 先端になるにしたがい層の㩐さ が薄くなっている。これは注入 现によるが，造影剤と血液と の不充分な斟利性を走するのと 思わ机る．更に血没の流動性老考慮した是顛 5 でもゴム 管下部の層形成がみられるが，血液と造影㓣在同時に注 入したため層形成に相違がみられ，造影剤だ㳡入した 場合より混和性は多少よいと思われる，乙の時の正面掫 影では側万问擬影の時の尿形成はみられず，あたかもゴ

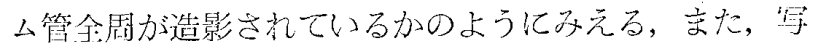
顛6の立位ではゴム管全周がよく造影されている。

\section{II臨 床 例}

1. 四肢の静脈造影においては，すでに体位を主位に して撮影するのが適当であるといわれているが，この点 については写真 7 の如く下肢静脈溜の患者を三方向上り 撮影してみた結果, 背卧位にて正面方向より撮影した造 影をみると前述の基礎実験と同様，血管全周が出現して いるように見受けられるが，これは側方向より撮影した 造影では全般に血管が細くみえる。乙れは血管の下部に

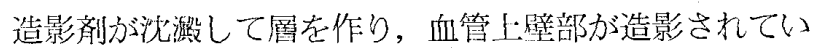
ないためと思われる，立位造影に扎いては，乙の現象が 解消され，血管全周が造影されて静脈留捛よび静脈升等 が明暸に出現している。

2. 下大静脈造影はその診断域の広いととから近年, 四肢の静脈造影以上に行なわれている. 写真8は下大静 脈造影の立位と背㘬位で撮影したものであるが，立位像 では血管全周が造影され，第 3 腰椎部で血管内縁に㓌影 久損が鮮明であるが背卧位像においては，はっきりとし た変化が認められない。それは病変が血管前壁のもので 背卧位では造影剂が血管の後壁を主に流れ，血管前壁が 光分に造影されていないためと思われる. 


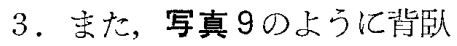
位と腹臥位での撮影を比較すると 背卧位では血管の内縁は椎体の前 方化重なり外縁は後斜方傾き造 影剂が外縁の低い部分に片寄って 流れ，血液と層を作るため陰影が 外緣では鮮鋭であるが，内緣では 造影剤は稀簙となり陰影が不鮮鋭 である。これに対し腹卧位では前 方に向管が移動するため，とのよ うな現象は血管自身の高低が活と んどなくなり血管前壁が造影され 队，外縁の陰影む一様に造影され ている.

4. 写真10は側方向撮影である が血管の後壁には造影剤が層を作 り，辽縁が鮮鋭に造影されている が，前壁の辺縁は不鮮鋭である。 また，背臥位の正面撮影ではやは り血管が傾き内緣の陰影には不鮮 鋭な部分が生じている。

5. 写真11む正常例の下大静脈

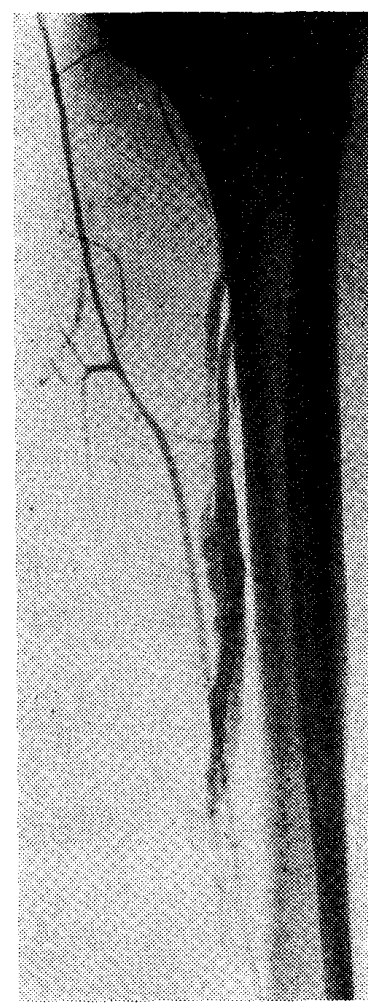

写真 7 : 左上り 背臥位正面…全周が造影されているが見受ける " 側面…全般的に細く片寄っている

" 立位 $\cdots$ 全周造影

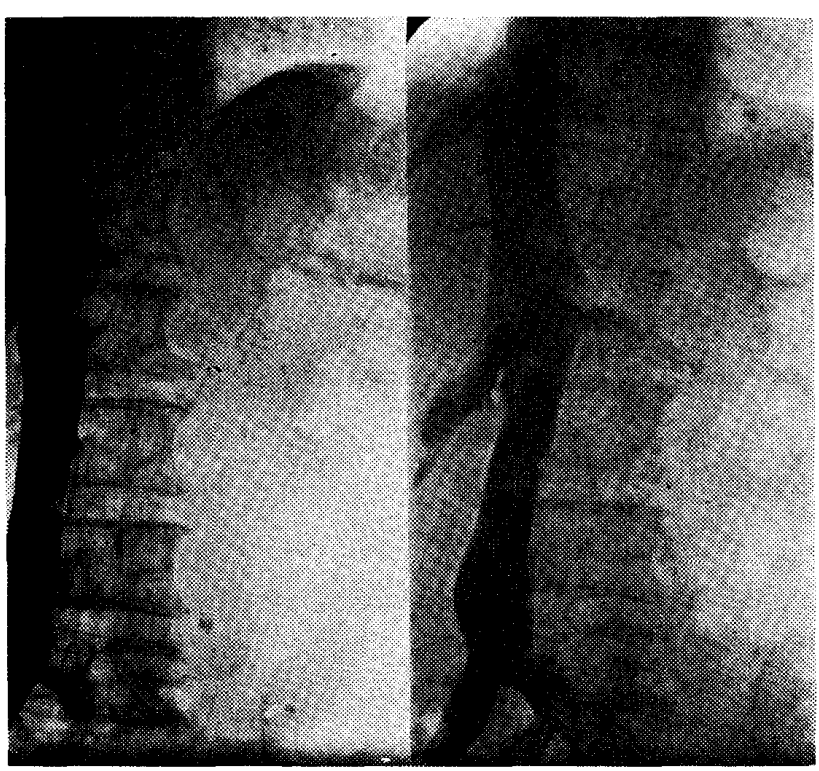

写真 8 : 左 背臥位 内縁不鮮鋭 右 立位 全周造影

造影で左右の股静脈より注入した立位と背臥位像である。 立位では内外縁が明暸であるが，背卧位においては内縁 が外縁に比較して不鮮鋭である.

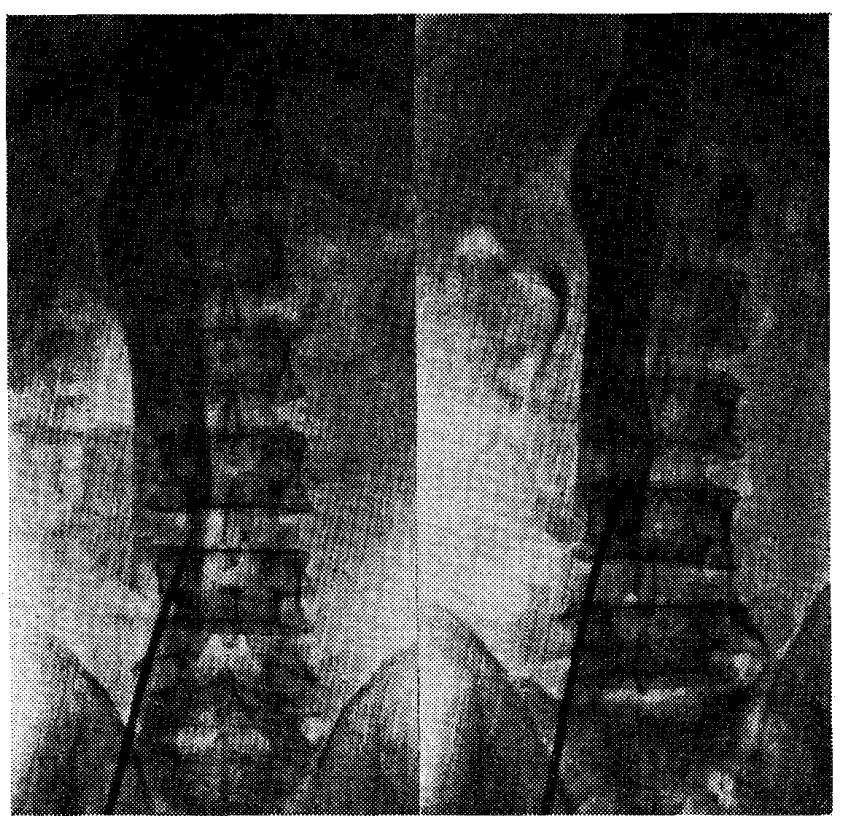

写真 9 : 左 背臥位 内縁不鮮鋭 右 腹臥位 内外縁共焦明。

\section{III 考 察}

以上，基礎的な実験と臨床例による検討を行なったが 


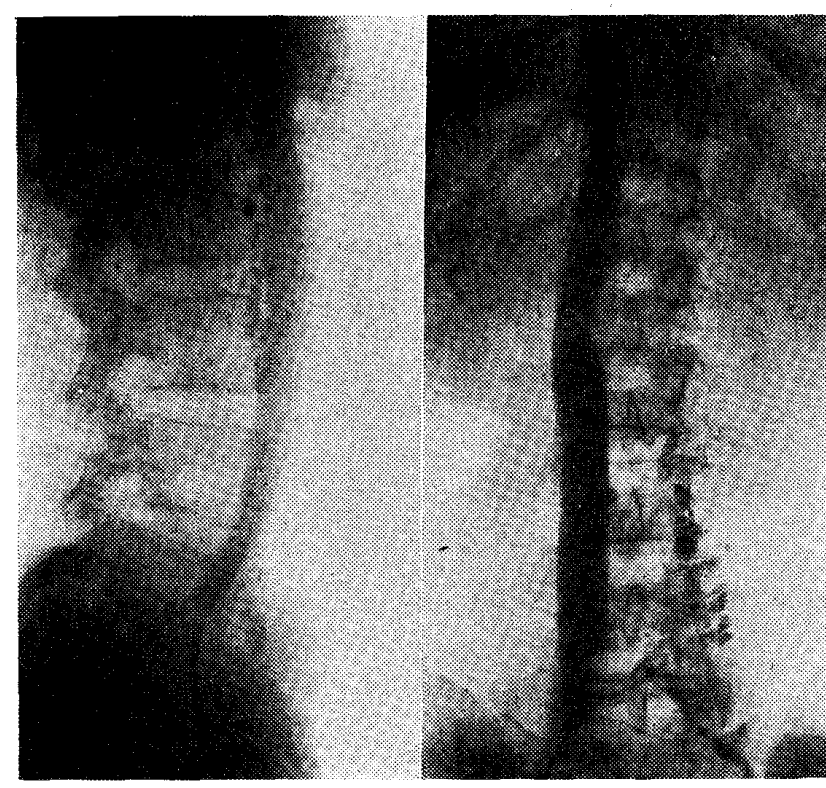

写真10 左 背臥位側面 前壁部不鮮鋭 在 背臥位正面 内縁不鮮釦

静脈造影においては，造影剂は血液と充分な混和去さ ず血管の低い部分に沈搌し，層を形成して流れ，血管径 の小さい下肢静脈造影においてむ，その現象が明膫であ った.

また，血管径の大きい下大静脈においてもこの現象は さらに著明にあらわれている，それは背卧位掫影では血 管が一部推体と重なって傾斜し，低く位置した血管外縁 に造影剂が層を作り外縁は比較的鮮鋭に造影されるが内 縁は高く位䈯しているので造影剂は稀薄となり外縁より 不鮮鋭汇造影される。このような現象をさけるため $\mathrm{He}$ lander 等) は出来るだけ濃度の低(造影剂を下大静脈 造影任使用すべきとだいうが，コントラストとのかねあ いもあり必ずしもそれが良いとはいえない。われわれの 基礎奏験から現在市販されている造影剂ではこの層形成 に対して浱度差の影響は少ないようである。この層形成 はカテーテルの側孔を多くあ讨急速汇造影剤を注入する ことによってもある程度さけられるが，必ずしあ常にさ けられるむのではない，乙のような場合に腹卧位での撮 影老行なうと腹臥位での血管の傾斜した状態は血管自身 が多少前方に移動するので，その高低はほ济一様になり 椎体と重なっていた部分も造影郕が流れるので血管内縁 も前壁とともによく造影される。乙のようなととから背 卧位で撮影すると所見が明らかでない場合に脊卧位で搌 影すると明確なる所見を得たり，背臥位で明らかではな い場合に立位にすると明確になったりするととがしばし

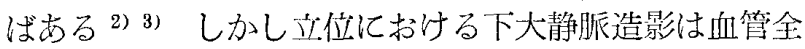

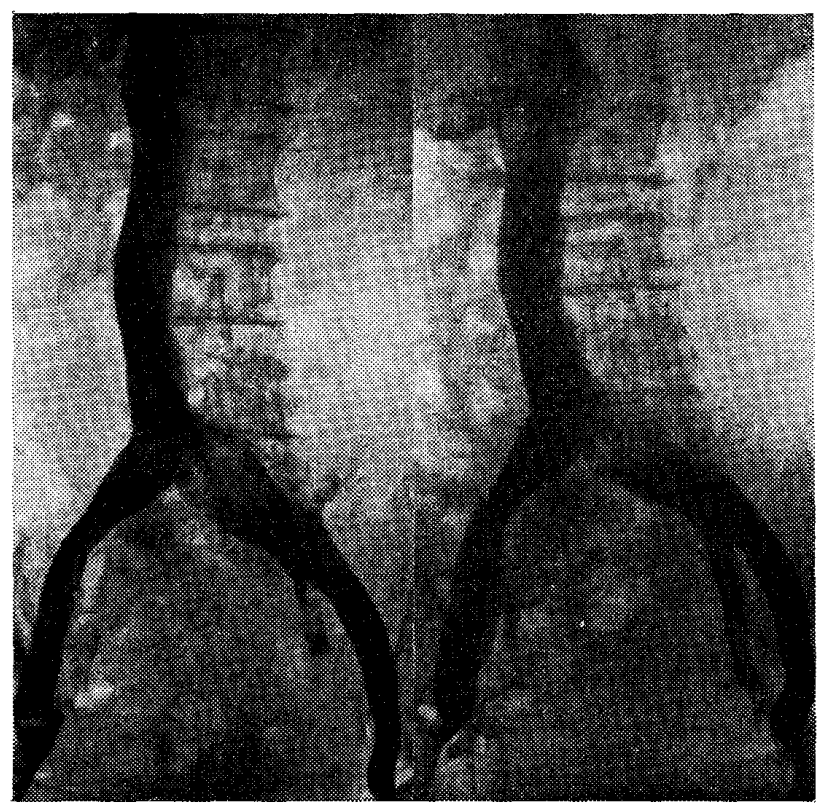

写真11 左 背臥位 内縁不鮮鋭 右 立位队 外縁共鮮明

周がよく造影されるにすかかわらず所見が不明瞭な場合 がある。，それは血液と造影剤が血管に充満し，静脈壁が 伸展した結果, 背臥位で腹腔藏器により圧迫されて生ず る陰影が立位になったため, その圧迫も軽度になるから であると思われるが，逆にとのため所見が明瞭になる場 合も尚る．乙の上うに臨床的にみられる現象は基礎実験 の結果とよく一致する, 以上のことから, 静脈造影は多 方向で，しかむ同時二方问連続撮影がもっとも理想的で あるが， ${ }^{4}$ とのような設硔の恩恵に浴するところは少な い。 そこで，普通の撮影台で行なう場合は背卧位，腹㸝 位での前後方向ないしは後前方向の撮影を行ない，事情 が許せば立位での正，側方向の撮影を加えれば造影剤の 比重からくる問題がある程度解決されるように思う。

\section{IV. まとめ}

以上，静脈造影飞执いて血液と造影剤の混和性につい て基礎的には試験管扰よび血管を仮定したゴム管を使用 し，臨床例においては撮影体位の変化による造影の比較 検討したが，市販の血管造影剤と血液との混和性はかな り恵く，血液と層形成をなし，種々な診断上好ましくな い点を生ずる. 通常行なわ机ている背卧位の前後方向の 静脈撮影だけでは不充分であり，静脈全周を造影ずるた めには他の撮影体位む追加する必要があるととを強調し た. 終わりに臨みご校閲を晹わりました阿武保郎教授, 終始丁寧なるご指導を下さいました本学勝部吉雄博士に 深甚なる感謝の意を表し，あわせて本研究にで協力下さ 
いました当部先輩諸氏に愿くお礼畃しあげます。（な 掠，本論文の装旨は第24回日放技学会総会一1968年，宗 都で口述発表した。）

\section{参考交献}

1) Helander, C. H. and Lindbom, A. : Venography of the inferior vena cava. Acta Radiol. 52, 257$268,1959$.
2）阿武保郎，勝部吉雄，石川䆖輔，白枝親司：下空静 脈造影の経験 臨牀放射線 13，468～475，1968.

3) Hayt, D. B. : Upright inferior vena cavography. Radiology 85, 865-870, 1966.

4) Cabriele, O. F., Bell, D. and Martinean, R. : Pitfalls in inferior vena cavography. Amer. J. Roentgenol. 100, 417-423, 1967.
X 線診断造影剤

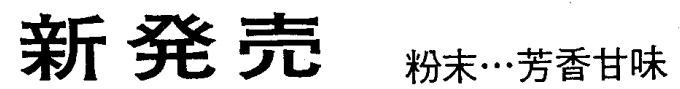

\section{ウムブラン゙ルーA}

製造特許 コンドロイチン硫酸ナトリウム使用

特長（1）胃酸による凝固は起さない

（2）レリーフ用、二重造影用

(3) バリウム濃度 $120 \%$ \% $/ v$ まで

混合容易

包装 $1.2 \mathrm{~K} .15 \mathrm{~K}(200 \mathrm{~g} \times 75.600 \mathrm{~g} \times 25$ 入 $)$

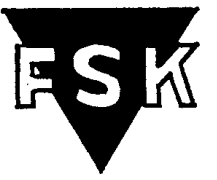

パロルトッ゙ンデラックス

粉末品

\section{バリトム゙タ・゙ル}

流動性 $100 \% \mathrm{w} / \mathrm{v}$

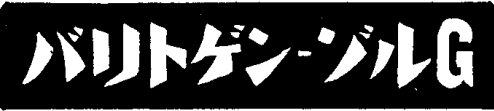

流動性 $75 \%$ w $/ v$

集団検診用

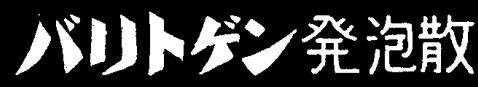

粉末品

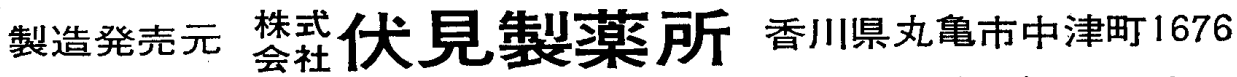

東京出張所 東京都中野区弥生町 2 の 41 の 6 TEL. (383) 4422

大阪出張所大阪市福島区上福島中 3 の 75 TEL. (448) $0471 \sim 2$ 